\title{
SCUBE2 wt Allele
}

National Cancer Institute

\section{Source}

National Cancer Institute. SCUBE2 wt Allele. NCI Thesaurus. Code C114307.

Human SCUBE2 wild-type allele is located in the vicinity of $11 \mathrm{p} 15.3$ and is approximately $119 \mathrm{~kb}$ in length. This allele, which encodes signal peptide, CUB and EGF-like domaincontaining protein 2 , may play a role in both cell-cell adhesion and cell proliferation. 